\title{
Oxidative Dimerization of Ru(III)-EDTA Complex on the Surface of Functionalized Silica Gel
}

\author{
Lúcia Codognoto, Patrícia Graça Zanichelli and Rosana Lázara Sernaglia*
}

Departamento de Química, Universidade Estadual de Maringá, Av. Colombo, 5790, 87020 - 900 Maringá - PR, Brazil

Este trabalho descreve um estudo da reação de ancoramento de $\mathrm{H}\left[\mathrm{Ru}(\mathrm{III}) \mathrm{Cl}_{2}\left(\mathrm{H}_{2} \mathrm{EDTA}\right)\right] .4 .5$ $\mathrm{H}_{2} \mathrm{O}$ na superfície da sílica gel funcionalizada (SF) com o composto [3-(2aminoetil)aminopropil]trimetoxissilano (AEATS), gerando por meio de ligação amida o composto dimérico (EDTA) ${ }_{2} \mathrm{Ru}_{2}(\mathrm{IV}, \mathrm{IV})$ na superfície da sílica modificada. A oxidação da água por esse complexo imobilizado na superfície da sílica foi observada pela formação de $\mathrm{O}_{2}$ e decréscimo do $\mathrm{pH}$, originando a sílica modificada SF-AEATS/(EDTA) $\mathrm{Ru}_{2}\left(\mathrm{III}_{1 / 2}, \mathrm{III}_{1 / 2}\right)$. Este dímero ancorado foi caracterizado por espectroscopia eletrônica e vibracional e também por espectroscopia de EPR. O comportamento eletroquímico de um eletrodo de pasta de carbono modificado com a sílica SFAEATS/(EDTA) ${ }_{2} \mathrm{Ru}_{2}\left(\mathrm{III}_{12}, \mathrm{III}_{1 / 2}\right)$ também foi estudado.

The present paper deals with the reaction of oxidative dimerization of the $\mathrm{H}\left[\mathrm{Ru}(\mathrm{III}) \mathrm{Cl}_{2}\left(\mathrm{H}_{2}\right.\right.$ EDTA)].4.5 $\mathrm{H}_{2} \mathrm{O}$ complex on the surface of silica gel functionalized (SF) with [3(2-aminoethyl)aminopropyl]trimethoxysilane (AEATS), generating the dimeric (EDTA) $\mathrm{Ru}_{2}$ (IV,IV) complex immobilized on the surface of this silica through the coordination with amide bonds. The oxidation of water by the anchored dimeric complex proceeded rapidly and was observed by the evolution of $\mathrm{O}_{2}$ and the decrease in $\mathrm{pH}$, yielding the SF-AEATS/(EDTA $)_{2} \mathrm{Ru}_{2}\left(\mathrm{III}_{1 / 2}, \mathrm{III}_{1 / 2}\right)$. This anchored dimer was characterized by electronic, vibrational and EPR spectroscopies. The electrochemical behavior of a modified carbon paste electrode prepared with SF-AEATS/ (EDTA) $)_{2} \mathrm{Ru}_{2}\left(\mathrm{III}_{1 / 2}, \mathrm{III}_{1 / 2}\right)$ was also studied.

Keywords: $\mathrm{Ru}(\mathrm{III})$-EDTA complex dimerization, modified silica gel, silica immobilized ruthenium edta dimer

\section{Introduction}

The synthesis and characterization of electroactive mono and polymetallic complexes of ruthenium (III)/(II) attached to solid supports have been the subject of extensive studies. These materials can be applied in areas such as catalysis and electroanalytical chemistry and, particularly as electron-transfer mediators in molecular devices and multielectron transfer catalysis. ${ }^{1-15}$

Our particular interest is focused on modified carbon paste electrodes made with functionalized silica gel with $\mathrm{Ru}(\mathrm{III}) /(\mathrm{II})$-EDTA complexes covalently immobilized on its surface. ${ }^{1-3,15-17}$ The synthetic route to support $\mathrm{Ru}(\mathrm{III})$ EDTA complex on the surface of silica gel functionalized with [3-(2-aminoethyl)aminopropyl]trimethoxysilane (AEATS) is similar to the one described by Anson et al. ${ }^{18}$ for the ethylenediaminetetraacetate complexes of ruthenium (II) and (III). The ruthenium complex was

\footnotetext{
* e-mail: rlsernaglia@uem.br
}

attached to graphite electrodes by amide bonds formed by the condensation of an uncoordinated acetate group in $\mathrm{Ru}(\mathrm{III})$-EDTA with amine groups introduced into the graphite surface by a plasma etching procedure. ${ }^{2}$

In this paper, amine groups are introduced onto the silica surface by silanization reaction with [3-(2aminoethyl)aminopropyl]trimethoxysilane, yielding SFAEATS. The reaction of this support with $\mathrm{H}\left[\mathrm{Ru}(\mathrm{III}) \mathrm{Cl}_{2}\left(\mathrm{H}_{2} \mathrm{EDTA}\right)\right] .4 .5 \mathrm{H}_{2} \mathrm{O}$ in the presence of dicyclohexylcarbodiimide (DCHC) in N,Ndimethylformamide (DMF) is presented. ${ }^{2}$

This reaction leads to the dimeric complex (EDTA) $\mathrm{Ru}_{2}(\mathrm{IV}, \mathrm{IV})$ attachments on the surface of the SFAEATS silica.

\section{Experimental}

All the chemicals used were Aldrich reagent grade unless otherwise specified, and the solvents were of AR grade and purified when necessary. ${ }^{19}$ Doubly distilled water 
was used throughout the work; $\mathrm{RuCl}_{3} . x \mathrm{H}_{2} \mathrm{O}$ was used as the starting material for the synthesis of the ruthenium complex.

The dicloro(dihydrogen ethylenediaminetetraacetate)ruthenate(III), $\mathrm{H}\left[\mathrm{Ru}(\mathrm{III}) \mathrm{Cl}_{2}\left(\mathrm{H}_{2}\right.\right.$ EDTA) $] .4 .5 \mathrm{H}_{2} \mathrm{O}$ acid complex was prepared and characterized following procedures previously described. ${ }^{20-22}$ The product, obtained in the form of yellow crystals, was readily soluble in water, ethanol and N,N'-dimethylformamide. (Found: C, 22.04; $\mathrm{H}, 4.10 ; \mathrm{N}, 4.99$, Anal Calc. for: C, 22.06; H, 4.44; N, $5.14 \%$ ). Elemental analyses were performed in the Microanalytical Laboratory of the University of São Paulo. The IR spectrum of the product was in agreement with the one reported by Mukaida. ${ }^{21}$

\section{Silanization reaction}

The silica gel-60 (SPA) (Aldrich, 70-230 mesh) with specific surface area of $506 \pm 6 \mathrm{~m}^{2} \mathrm{~g}^{-1}$ was activated by heating under vacuum at $423 \mathrm{~K}$ for $8 \mathrm{~h}$. A $5 \%$ solution of [3-(2-aminoethyl)aminopropyl]trimethoxysilane $\left(\left(\mathrm{CH}_{3} \mathrm{O}\right)_{3} \mathrm{Si}\left(\mathrm{CH}_{2}\right)_{3} \mathrm{NH}\left(\mathrm{CH}_{2}\right)_{2} \mathrm{NH}_{2}\right)$ was prepared in anhydrous toluene. The silica gel was refluxed and stirred for $16 \mathrm{~h}$ in silane solution under nitrogen atmosphere. After silylation, the solid was filtered and washed with anhydrous ethanol in a Soxhlet extractor for $16 \mathrm{~h}$. Finally, the silylated silica gel was dried under vacuum $\left(\# 10^{-4} \mathrm{mmHg}\right.$ ) for $8 \mathrm{~h}$ at 393 $\mathrm{K}$, yielding SF-AEATS, with the silane ethylenediamine (silane en) bonded to the silica gel surface. ${ }^{23}$

\section{Immobilization of $R u(I I I)-E D T A$}

The $\mathrm{H}\left[\mathrm{Ru}(\mathrm{III}) \mathrm{Cl}_{2}\left(\mathrm{H}_{2}\right.\right.$ EDTA $\left.)\right] .4 .5 \mathrm{H}_{2} \mathrm{O}$ complex was supported on the surface of the SF-AEATS silica with the (silane en) through amide bonds. ${ }^{1-3}$ The SF-AEATS silica $(0.50 \mathrm{~g})$ was added to a solution of dicyclohexylcarbodiimide $(0.35 \mathrm{~g})$, in anhydrous DMF (50 mL). Next, a solution of Ru(III)-EDTA complex $(0.23 \mathrm{~g}$ in $10 \mathrm{~mL}$ of DMF) was slowly added and the resulting suspension was refluxed and stirred for $4 \mathrm{~h}$ under nitrogen atmosphere. The suspension was cooled to room temperature and the solid was filtered and washed with DMF and anhydrous ethanol and ether. The resulting brown solid was dried under vacuum for $6 \mathrm{~h}$ at $393 \mathrm{~K}$. This brown solid was added to water and $\mathrm{pH}$ measurements were taken. A rapid evolution of $\mathrm{O}_{2}$ (Clark electrode was used to confirm the evolution of $\mathrm{O}_{2}$ ) and a $\mathrm{pH}$ decrease were observed. The resulting dark brown solid was separated by filtration, washed with ethanol and ether, dried under vacuum for $4 \mathrm{~h}$ at $393 \mathrm{~K}$ and stored under vacuum.

\section{Chemical analysis (nitrogen sites)}

The amount of nitrogen in the sample of SF-AEATS was quantified taking advantage of its basic character. ${ }^{24}$ In a typical example, $0.200 \mathrm{mg}$ of the SF-AEATS silica were added to $25.0 \mathrm{~mL}$ of standard $\mathrm{HCl}\left(0.104 \mathrm{~mol} \mathrm{~L}^{-1}\right)$ solution in a thermostatized cell $\left(25.0{ }^{\circ} \mathrm{C}\right)$, reacting for one hour. The conductivity of the system was measured before and after the reaction. The excess of acid was determined by means of conductivity variation and used to calculate the amount of nitrogen sites. In this case $(17.2 \pm 0.3) \times 10^{-4} \mathrm{~mol}$ $\mathrm{g}^{-1}$ was found. The functionalization efficiency was determined for (silane en) groups as being equal to (8.6 \pm 0.3) $\times 10^{-4} \mathrm{~mol} \mathrm{~g}^{-1}$ in the SF-AEATS based on the nitrogen content.

For the ruthenium elemental analysis, the dark brown silica was previously treated with a mixture of $\mathrm{HF} / \mathrm{HClO}_{4} /$ $\mathrm{HNO}_{3}$ as described in the literature, ${ }^{25}$ and ruthenium was analyzed by means of atomic absorption.

The specific area of the silica surface was determined by BET method. ${ }^{25}$

The surface (silane en) groups density $(\delta)$ and their average interatomic distance (1) were calculated, ${ }^{26}$ assuming that the (silane en) groups were uniformly distributed on the surface by applying equations 1 and 2 .

$\delta=\frac{N_{0} N}{S_{B E T}}$

$l=\left(S_{B E T} / N_{0} N\right)^{1 / 2}$

where $\mathrm{N}_{0}$ is the amount of (silane en) attached to the surface, $\mathrm{N}$ is the Avogadro's number and $\mathrm{S}_{\mathrm{BET}}$ is the specific area.

\section{Electronic spectra}

The electronic spectra for the immobilized species were obtained with the solid suspended in $\mathrm{CCl}_{4}$, using a 0.10 $\mathrm{cm}$ path length quartz cell and a DU-70 Beckman spectrophotometer.

\section{Cyclic voltammetry}

All electrochemical studies were performed using a three-electrode potentiostatic system (Priceton Applied Research assembly including a potentiostat - galvanostat (model 263A) coupled to an IBM - PC computer). The modified carbon paste electrode used as the working electrode was prepared by carefully mixing $20 \mathrm{mg}$ of either SF-AEATS or SF-AEATS/(EDTA) ${ }_{2} \mathrm{Ru}_{2}\left(\mathrm{III}_{1 / 2}, \mathrm{III}_{1 / 2}\right)$ with 30 $\mathrm{mg}$ of graphite powder and nujol oil, pressing the mixture 
onto a platinum grid (total area, $0.2 \mathrm{~cm}^{2}$ ). The studies in the electrochemical cell were performed under argon atmosphere.

The electrochemical behavior of such electrodes was analyzed by cyclic voltammetry and the ionic strength $\left(0.80 \mathrm{~mol} \mathrm{~L}^{-1}\right)$ was controlled with sodium trifluoracetate $\left(\mathrm{NaCF}_{3} \mathrm{COO}\right)$, at $25.0 \pm 0.5^{\circ} \mathrm{C}$. The potentials were reported to $\mathrm{Ag} / \mathrm{AgCl}$ (satured $\mathrm{KCl}$ ) electrode, double junction Orion model $90-02\left(\mathrm{E}^{\circ}=0.197 \mathrm{~V} v s\right.$. $\mathrm{SHE}$, at $\left.25^{\circ} \mathrm{C}\right)$. A platinum wire was used as an auxiliary electrode and the modified carbon paste electrode (CPE) was used as a working electrode.

The comproportionation constant $\left(\mathrm{K}_{\mathrm{c}}\right)^{27}$ was calculated by equation 3 :

$K_{c}=\exp \left[\frac{\left(E_{1}^{0}-E_{2}{ }^{0}\right) n_{1} n_{2} F}{R T}\right]$

where $\mathrm{E}^{0}=$ midpoint potential, $\mathrm{n}=$ number of electrons, $\mathrm{F}$ $=$ Faraday constant. When $\mathrm{n}_{1}=\mathrm{n}_{2}=1, \mathrm{~K}_{\mathrm{c}}=\exp \left(\Delta \mathrm{E}_{0} / 25.69\right)$ at $298 \mathrm{~K}$, with $\Delta \mathrm{E}_{0}$ given in $\mathrm{mV}$.

\section{Infrared spectra}

The infrared spectrum of the self-supported disk of the material was obtained without any dilution of the immobilized complexes with $\mathrm{KBr}$. The equipment used was an FT-IR Bome Hertmann \& Braum, model MB100 spectrophotometer with sample disk containing approximately $10 \mathrm{mg} \mathrm{cm}^{-2}$.

\section{Electron paramagnetic resonance spectra}

Low temperature electron paramagnetic resonance (EPR) spectra were measured using a Bruker ESP-300E spectrometer operating at X-band frequencies at $77 \mathrm{~K}$. The EPR spectra were obtained at the Instituto de Química de São Carlos, USP - São Carlos.

\section{Thermogravimetric Analysis (TGA)}

TGA curves were obtained in a Shimadzu (TGA-50) thermogravimetric analyser, at a heating rate of $20^{\circ} \mathrm{C} \mathrm{min}^{-1}$, in the range of 25 to $1000{ }^{\circ} \mathrm{C}$ and under $\mathrm{N}_{2}$ atmosphere flowing at $10 \mathrm{~mL} \mathrm{~min}^{-1}$.

\section{Results and Discussion}

The immobilization ${ }^{1-3}$ of $\mathrm{H}\left[\mathrm{Ru}(\mathrm{III}) \mathrm{Cl}_{2}\left(\mathrm{H}_{2}\right.\right.$ EDTA)] complex on functionalized silica gel SF-AEATS was achieved by the condensation of the uncoordinated acetate groups of $\mathrm{Ru}(\mathrm{III})$-EDTA with amine groups (silane en) of SF-AEATS. Approximately $2.0 \times 10^{-4}\left(\mathrm{~mol} \mathrm{~g}^{-1}\right) \mathrm{mol}$ of $\mathrm{Ru}$ were immobilized per $g$ of silica, implying that $23 \%$ of the nitrogen sites were bonded to the metal centers. A decrease in the surface area of the silica with the functionalization of (silane en) groups was observed. The specific area of the silica decreased from $506 \pm 6 \mathrm{~m}^{2} \mathrm{~g}^{-1}$ to $337 \pm 6 \mathrm{~m}^{2} \mathrm{~g}^{-1}$, probably due to the blocking of the pores with the coupling of (silane en) groups on its surface. ${ }^{12}$ The value of $(1.5 \pm$ $0.1) \times 10^{18} \mathrm{M}^{-2}$ was obtained for the surface bonded (silane en) groups density. Based on equation 2, the estimated value for the average distance between two AEATS groups was $8.1 \pm 0.3 \AA$. This distance could be considered an estimate of the minimum average distance necessary for two metal centers immobilized by amide bonds undergoing oxidative dimerization reactions on the surface of the SF-AEATS or vice-versa.

The specific area of the solid after anchoring the metal complex decreases to $320 \pm 6 \mathrm{~m}^{2} \mathrm{~g}^{-1}$.

Besides the immobilization of the ruthenium complex, metal centers in high oxidation states were observed, probably due to the formation of (EDTA) $\mathrm{Ru}_{2}(\mathrm{IV}, \mathrm{IV})$ dimer.

Upon contact of SF-AEATS/(EDTA) ${ }_{2} \mathrm{Ru}_{2}(\mathrm{IV}, \mathrm{IV})$ with water, a copious gas evolution $\left(\mathrm{O}_{2}\right)$ and an increase in the solution hydrogen ion concentration $(3 \mathrm{pH}$ units, for 20 $\mathrm{mg}$ of solid) were observed. A dimeric complex was produced according to the reaction :

$$
\begin{aligned}
& 2 \mathrm{H}_{2} \mathrm{O}+4\left((\text { EDTA })_{2} \mathrm{Ru}_{2}(\mathrm{IV}, \mathrm{IV})\right) \stackrel{\text { cat. }}{\longrightarrow} \mathrm{O}_{2}+ \\
& 4\left((\text { EDTA })_{2} \mathrm{Ru}_{2}\left(\mathrm{III}_{1 / 2}, \mathrm{III}_{1 / 2}\right)\right)+4 \mathrm{H}^{+}
\end{aligned}
$$

on the surface of the SF-AEATS silica, yielding the SFAEATS/(EDTA) $)_{2} \mathrm{Ru}_{2}\left(\mathrm{III}_{1 / 2}, \mathrm{III}_{1 / 2}\right)$.

The infrared spectrum of the SF-AEATS/ (EDTA) ${ }_{2} \mathrm{Ru}_{2}\left(\mathrm{III}_{1 / 2}, \mathrm{III}_{1 / 2}\right)$ was an important evidence for amide bond formation in the immobilization of the complex by covalent Ru-N (amide) bonds. Table 1 shows the main infrared frequencies observed in the spectrum of the anchored complex. The spectrum shows the three characteristic bands of amide bonds, i.e., $1658 \mathrm{~cm}^{-1}(v$ $(\mathrm{C}=\mathrm{O})), 1573 \mathrm{~cm}^{-1}$ and a shoulder at $1464 \mathrm{~cm}^{-1}(v(\mathrm{C}-\mathrm{N})+\delta$ $(\mathrm{N}-\mathrm{H})$ in the plane). ${ }^{28}$

The electron paramagnetic resonance spectrum of the SF-AEATS/(EDTA) $)_{2} \mathrm{Ru}_{2}\left(\mathrm{III}_{1 / 2}, \mathrm{III}_{1 / 2}\right.$ ) sample was recorded at $77 \mathrm{~K}$, and is shown in Figure 1.

Three g-values were extracted from the EPR spectrum (2.01, 2.25 and 2.39). The spectrum was consistent with the presence of a single unpaired electron confined in an unsymmetrical environment. The signals are in the typical region for $\mathrm{Ru}(\mathrm{III})$ compounds and reflect the low symmetry of the dimeric complex. The rhombic anisotropy in Figure 
Table 1. Infrared absorption frequencies of silica SPA, SF-AEATS and SF-AEATS/(EDTA) ${ }_{2} \mathrm{Ru}_{2}\left(\mathrm{III}_{1 / 2}, \mathrm{III}_{1 / 2}\right)$

\begin{tabular}{|c|c|c|c|c|}
\hline SPA & SF-AEATS & $\mathrm{SF}-\mathrm{AEATS} / \mathrm{Ru}_{2}$ & $\mathrm{SF}-\mathrm{AEATS} / \mathrm{Ru}_{2}(v s$. SPA) & Attributions \\
\hline \multirow[t]{2}{*}{3400 (vs, br) } & $3400(\mathrm{~s}, \mathrm{br})$ & 3400 (vs, br) & $3400(\mathrm{~s}, \mathrm{br})$ & $v-\mathrm{OH}$ \\
\hline & $2940(\mathrm{~m})$ & $2950(\mathrm{~m})$ & 2937 (w) & $v-\mathrm{CH}_{2}$ \\
\hline $1992(w)$ & $1990(\mathrm{~m})$ & $1987(\mathrm{~m})$ & $1987(\mathrm{~m})$ & (a) \\
\hline $1870(w)$ & $1870(w)$ & $1870(\mathrm{~m})$ & & (a) \\
\hline \multirow[t]{9}{*}{$1637(\mathrm{~s})$} & $1634(\mathrm{~m})$ & & & $\delta-\mathrm{HOH}$ \\
\hline & & & $1658(w)$ & $v(\mathrm{C}=\mathrm{O})$ \\
\hline & & 1625 (vs, br) & & $\delta-\mathrm{HOH}+v(\mathrm{C}=\mathrm{O})$ \\
\hline & & & $1573(\mathrm{~s})$ & $\delta-(\mathrm{N}-\mathrm{H})+v(\mathrm{C}-\mathrm{N})$ \\
\hline & 1560 (w, br) & & & $\delta-\mathrm{NH}_{2}$ \\
\hline & & $1464(\mathrm{sh})$ & $1464(\mathrm{sh})$ & $\delta-(\mathrm{N}-\mathrm{H})+v(\mathrm{C}-\mathrm{N})$ \\
\hline & $1480(w)$ & $1453(\mathrm{~m})$ & $1453(\mathrm{~m})$ & $\delta-\mathrm{CH}_{2}-\mathrm{N}$ \\
\hline & $1418(w)$ & & & $\delta-\mathrm{Si}-\mathrm{CH}_{2}$ \\
\hline & & $1389(\mathrm{~m})$ & $1381(\mathrm{~s})$ & $v_{s}\left(\mathrm{COO}^{-}\right)^{-}$ \\
\hline
\end{tabular}

(a) Silica skeleton combinations (reference 28) ; (s) strong; (w) weak; (br) broad; (sh) shoulder; (vs) very strong; (vw) very weak.

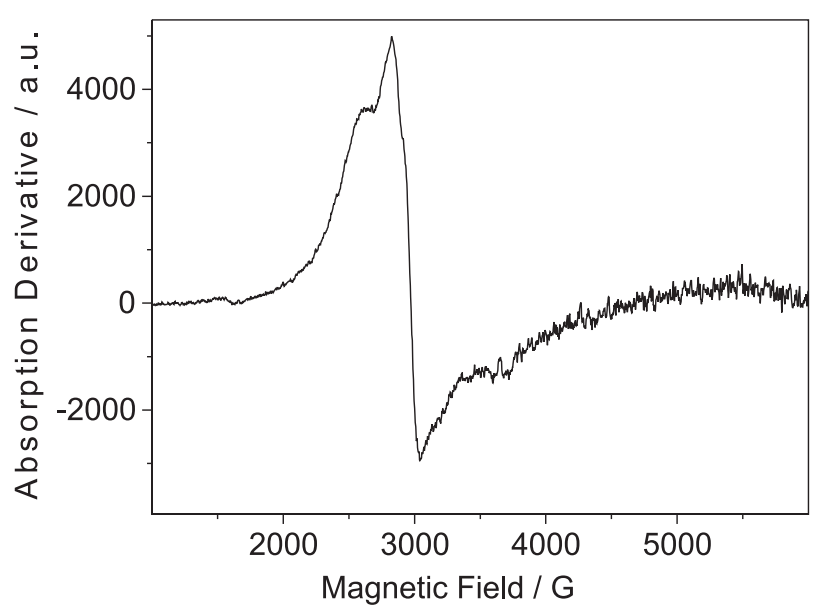

Figure 1. Electron Paramagnetic Resonance (EPR) spectrum of SFAEATS/(EDTA $)_{2} \mathrm{Ru}_{2}\left(\mathrm{III}_{1 / 2}, \mathrm{III}_{1 / 2}\right)$.

1 indicates that the unpaired electron is substantially delocalized in the bridging ligand. ${ }^{29}$

The thermoanalytical data obtained by TGA analysis of silicas SPA, SF-AEATS and SF-AEATS/(EDTA) ${ }_{2} \mathrm{Ru}_{2}\left(\mathrm{III}_{1 / 2}\right.$, III $_{1 / 2}$ ) indicate a similar thermal behavior in an $\mathrm{N}_{2}$ atmosphere. The mass loss occurs in two steps: up to 400.0 $\pm 0.5 \mathrm{~K}$, which is attributed to the loss of $\mathrm{H}_{2} \mathrm{O}$ and between $453.0 \pm 0.5$ and $813.0 \pm 0.5 \mathrm{~K}$, attributed to the loss of the organofuntional groups.

The SF-AEATS/(EDTA) $)_{2} \mathrm{Ru}_{2}\left(\mathrm{III}_{1 / 2}, \mathrm{III}_{1 / 2}\right)$ showed $21.8 \%$ of total mass loss whereas SF-AEATS presented a loss of $16.2 \%$. This difference indicates the loss of weighed groups of SF-AEATS/(EDTA) ${ }_{2} \mathrm{Ru}_{2}\left(\mathrm{III}_{1 / 2}, \mathrm{III}_{1 / 2}\right)$ surface, confirming the presence of the dimeric complex of Ru(III)-EDTA adsorbed in that modified material.

The electronic spectrum of the SF-AEATS silica modified with the reduced ruthenium dimeric complex, $\mathrm{Ru}_{2}\left(\mathrm{III}_{1 / 2}, \mathrm{III}_{1 / 2}\right)$, (Figure 2) showed the presence of a band at $\lambda_{\max }=940 \pm 10 \mathrm{~nm}$, with bandwidth value at half intensity of $\Delta v_{1 / 2}=6152 \mathrm{~cm}^{-1}$. This band was tentatively attributed as being due to the $\mathrm{Ru}(\mathrm{III})-\mathrm{Ru}(\mathrm{IV})$ intervalence transition (IT) of the Ru(III)-Ru(IV) dimer anchored on the SF-AEATS silica surface by comparison with the similar compound described in the literature (IT, $\lambda_{\max }$ at $632 \mathrm{~nm}$ ). ${ }^{18}$ Two more absorption bands were observed in the electronic spectrum for the supported complex: $\lambda_{\max }$ at $370 \mathrm{~nm}$ and at $470 \mathrm{~nm}$ (insert in Figure 2).

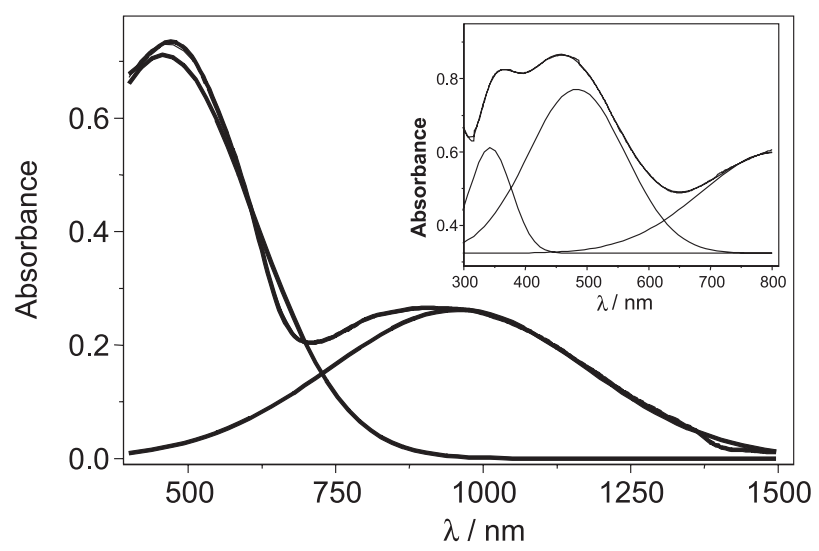

Figure 2. Electronic spectrum (in $\mathrm{CCl}_{4}$ ) of the SF-AEATS modified silica with the $\mathrm{H}\left[\mathrm{Ru}(\mathrm{III}) \mathrm{Cl}_{2}\left(\mathrm{H}_{2}\right.\right.$ EDTA $\left.)\right]$ complex. Insert: with deconvolution.

The electrochemical studies performed with a modified carbon paste electrode prepared with SF-AEATS/ (EDTA) $)_{2} \mathrm{Ru}_{2}\left(\mathrm{III}_{1 / 2}, \mathrm{III}_{1 / 2}\right.$ ) are also consistent with the presence of the $\mathrm{Ru}\left(\mathrm{III}_{1 / 2}, \mathrm{III}_{1 / 2}\right)$ dimeric complex, on the SF-AEATS silica surface.

Figure 3 shows the cyclic voltammograms of this modified carbon paste electrode $\left(\mu=0.8 \mathrm{~mol} \mathrm{~L}^{-1}\right.$ in $\mathrm{NaCF}_{3} \mathrm{COO}$, to $25.0 \pm 0.5^{\circ} \mathrm{C}$ ) at various scan rates, in the potential range of 0.700 to $-0.700 \mathrm{~V}$ ( $v s . \mathrm{Ag} / \mathrm{AgCl}$ ). The electroactive species presents two midpoint potentials, i.e., 
$\mathrm{E}_{1 / 2}=-0.215 \pm 0.10 \mathrm{~V}$ and $\mathrm{E}_{1 / 2}=0.090 \pm 0.10 \mathrm{~V}$. A plot of peak current $(\mu \mathrm{A})$ versus scan rate $\left(\mathrm{V} \mathrm{s}^{-1}\right)$ in the two processes is linear up to $50 \mathrm{mV} \mathrm{s}^{-1}$.

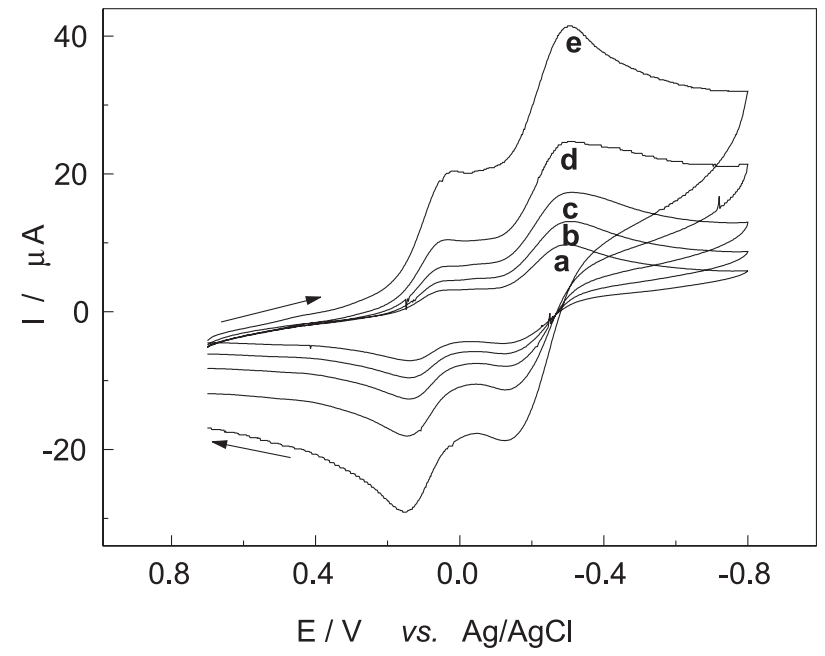

Figure 3. Cyclic voltammograms of SF-AEATS/(EDTA) $)_{2} \mathrm{Ru}_{2}\left(\mathrm{III}_{1 / 2}\right.$,

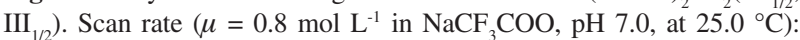
a) $10 \mathrm{mV} \mathrm{s}^{-1}$, b) $20 \mathrm{mV} \mathrm{s}^{-1}$, c) $30 \mathrm{mV} \mathrm{s}^{-1}$, d) $50 \mathrm{mV} \mathrm{s} \mathrm{s}^{-1}$ and e) $100 \mathrm{mV} \mathrm{s}^{-1}$.

The electrochemical behavior of this electroative anchored species is similar to the one described for the $\mathrm{Ru}\left(\mathrm{III}_{1 / 2}\right)-\mathrm{Ru}\left(\mathrm{III}_{1 / 2}\right)$ dimer complex characterized by Baar and Anson: ${ }^{18}$

$$
\begin{aligned}
& {[\mathrm{Ru}(\mathrm{IV})-\mathrm{Ru}(\mathrm{III})] \rightleftharpoons[\mathrm{Ru}(\mathrm{III})-\mathrm{Ru}(\mathrm{III})] \quad \mathrm{E}_{1 / 2}=0.090 \mathrm{~V}} \\
& {[\mathrm{Ru}(\mathrm{III})-\mathrm{Ru}(\mathrm{III})] \rightleftharpoons[\mathrm{Ru}(\mathrm{III})-\mathrm{Ru}(\mathrm{II})] \quad \mathrm{E}_{1 / 2}=-0.215 \mathrm{~V}}
\end{aligned}
$$

From the electrochemical data and assuming the formation of the symmetric binuclear complex, the comproportionation constant $\left(\mathrm{K}_{\mathrm{c}}\right)$ for reaction:

$[\mathrm{Ru}(\mathrm{IV})-\mathrm{Ru}(\mathrm{III})]+[\mathrm{Ru}(\mathrm{III})-\mathrm{Ru}(\mathrm{II})] \stackrel{\mathrm{K}_{\mathrm{c}}}{\rightleftharpoons} 2[\mathrm{Ru}(\mathrm{III})-\mathrm{Ru}(\mathrm{III})]$

was estimated as $\mathrm{K}_{\mathrm{c}}=1 \times 10^{5}$, suggesting a considerable coupling between the metallic centers.

The anchored dimer exhibits $\mathrm{pH}$-dependent $\mathrm{E}_{1 / 2}$ values at low $\mathrm{pH}$ for the two electrochemical processes. From Pourbaix plots ( $\mathrm{pH} v s . \mathrm{E}_{1 / 2}$, Figure 4 ) the $\mathrm{pK}_{\mathrm{a}}$ values of 3.3 \pm 0.2 for the (EDTA) ${ }_{2} \mathrm{Ru}_{2}\left(\mathrm{III}_{1 / 2}, \mathrm{III}_{1 / 2}\right)$ anchored dimer and $3.5 \pm 0.2$ for the (EDTA) ${ }_{2} \mathrm{Ru}_{2}$ (III,III) species were calculated. These $\mathrm{pK}_{\mathrm{as}}$ values were assigned to the single uncoordinated carboxylate group of the EDTA ligant also present in the dimer complex.

According to the voltammetry data the anchored species in the silica surface do not lixiviate significantly (less than $10^{-7} \mathrm{~mol} \mathrm{~L}^{-1}$ ) even at $\mathrm{pH} \# 7.0$ for a period of 4 hours.

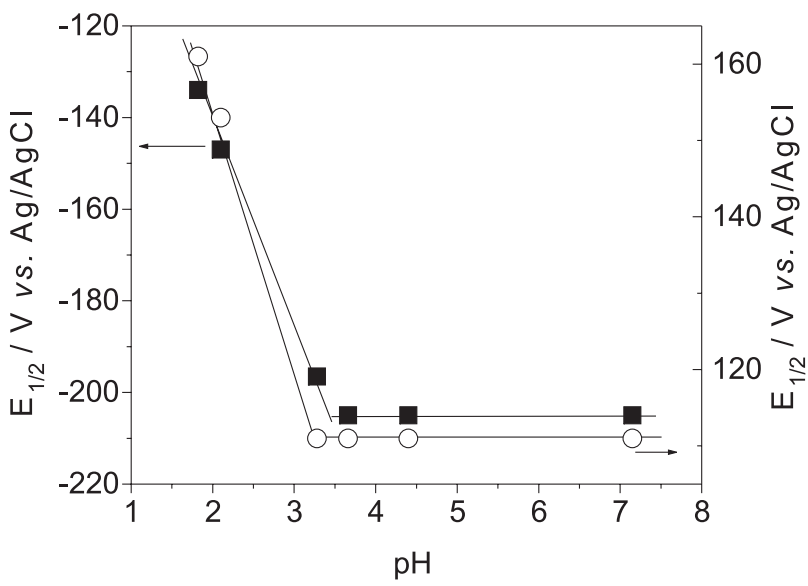

Figure 4. Variation of $\mathrm{E}_{1 / 2}$ as a function of $\mathrm{pH}$ of the supporting SFAEATS/(EDTA) ${ }_{2} \mathrm{Ru}_{2}\left(\mathrm{III}_{1 / 2}, \mathrm{III}_{1 / 2}\right)$ silica; $\left(\mu=0.2 \mathrm{~mol} \mathrm{~L}^{-1}\right.$ in $\mathrm{NaCF}_{3} \mathrm{COO}$, $20 \mathrm{mV} \mathrm{s}^{-1}$ at $25.0^{\circ} \mathrm{C}$ ).

\section{Conclusions}

The results are consistent with the ruthenium dimeric complex (EDTA) $)_{2} \mathrm{Ru}_{2}\left(\mathrm{III}_{1 / 2}, \mathrm{III}_{1 / 2}\right)$ immobilization with two metal centers immobilized by Ru-N (amide) bonds. This dimeric complex posseses a diamide- bridged and, at least, an uncoordinated carboxylate group in the metal center.

Studies of reactivity and catalytic activity of these supported species are also in development and results will be soon reported.

\section{Acknowledgments}

The authors would like to acknowledge CAPES and $\mathrm{CNPq}$ for the financial support given to this research. They are also indebted to Prof. Douglas Wagner Franco and Prof. Angela C. Pregnolato Giampedro for reading the final version of the manuscript.

\section{References}

1. Oyama, N.; Anson, F. C.; J. Electroanal. Chem. 1978, 88, 289.

2. Oyama, N.; Broson, A. P.; Anson F. C.; J. Electroanal. Chem. 1978, 87, 435.

3. Oyama, N.; Anson, F. C.; J. Am. Chem. Soc. 1979, 101, 1634.

4. Abruña, H. D.; Meyer, T. J.; Murray R. W.; Inorg. Chem. 1979, 18, 3233.

5. Murray, R. W.; Acc. Chem. Res. 1980, 13, 135.

6. Calvert, J. M.; Meyer, T. J.; Inorg. Chem. 1982, 21, 3978.

7. Chidsey, C. E. D.; Murray, R. W.; Science 1986, 231, 25.

8. Abruña, H. D.; Coord. Chem. Reviews 1988, 86, 135.

9. Hidalgo-Luangdilok, C. H.; Bocarsly, A. B.; Inorg. Chem. 1990, 29, 2894. 
10. O’Shea, T. J.; Leech, D.; Smyth, R. M.; Vos, J. G.; Talanta 1992, 39, 443.

11. Toma, H. E.; Matsumoto, F. M.; Cipriano, C.; J. Electroanal. Chem. 1993, 346, 261.

12. Neiva, S. M. C.; Santos, J. A.V.; Moreira, J. C.; Gushikem, Y.; Vargas, H.; Franco, D. W.; Langmuir 1993, 9, 2982.

13. Peixoto, C. R. M.; Kubota, L. T.; Gushikem, Y.; Anal. Proc. 1995, 32, 503.

14. Gushikem, Y.; Peixoto, C. R. M.; Rodrigues-Filho,U. P.; Kubota, L. T.; Stadler, E.; J. Colloid Interface Sci. 1996, 184, 236.

15. Lazarin, A. M.; Sernaglia, R. L.; Quim. Nova 1999, 22, 342.

16. Toma, H. E.; Sernaglia, R. L.; Talanta 1993, 40, 515.

17. Toma, H. E.; Sernaglia, R. L.; Talanta 1995, 42, 1867.

18. Baar, R. B.; Anson, F. C.; J. Eletroanal. Chem. 1985, 187, 265.

19. Perrin, D.; Armarego, W. L. F.; Perrin, D. R.; Purification of Laboratory Chemicals, Pergamon Press Ltd.: Oxford, 1980.

20. Yoshino, Y.; Uehiro, T.; Saito, M.; Bull. Chem. Soc. Jpn. 1979, $52,160$.

21. Mukaida, M.; Okuno, H.; Ishimori, T.; Nippon Kagaku Sasshi 1965, 86, 589.
22. Matsubara, T.; Creutz, C.; Inorg. Chem. 1979, 18, 1956.

23. Burggraf, L. W.; Kendall, D. S.; Leyden, D. E.; Pern, F.; J. Anal. Chim. Acta 1981, 129, 19.

24. Skopenko, V. V.; Trofimchuk, A. K.; Kaminskii, V. P.; Soviet Prog. Chem. 1982, 48, 14.

25. Loon, J. C. V.; Selected Methods of Trace Metal Analysis Biological and Environmental Samples, John Wiley \& Sons: New York, 1985.

26. Iler, R. K.; The Chemistry of Silica, John Wiley \& Sons: New York, 1977.

27. Denofre, S.; Gushikem, Y.; Castro, S. C.; Kawano, Y.; J. Chem. Soc. Faraday Trans. 1993, 89, 1057.

28. Colthup, N. B.; Daly, L. H.; Wiberley, S. E.; Introduction to Infrared and Raman Spectroscopy, $4^{\text {th }}$ ed., Acad. Press, Inc.: New York, 1969.

29. Matsumoto, K.; Matsumoto, T.; Kawano, M.; Ohnuki, H.; Shichi, Y.; Nishide, T.; Sato, T.; J. Am. Chem. Soc. 1996, 118, 3609 .

Received: March 10, 2003 Published on the web: March 21, 2005 